\title{
CP4-2
}

\section{CT angiography}

大阪大学大学院 医学系研究科 診療画像情報学 高橋 哲

マルチスライス CT の普及は、画像診断に大きな変化をもたらした。すなわち $1 \mathrm{~mm}$ あるいはそれ下の thinslice image の撮影が可能となり、高空間分解能画像を呼吸停止下に広範囲にわたって得る事ができるようになっ た。このため非常に高精細な 3 次元血管像すなわち CT angiography が得られるようになり、その画質は少なくと も大動脈造影は凌駕し、選択的腎動脈造影に迫るものがある。また横断像以外の多断面再構成画像（MPR: multiplanar reformat) も等方ボクセル (Isotropic voxel) が臨床上可能となった事により、高精細な任意のスライス断面 が得られる事はもはや MRIだけの利点ではなくなった。

腎腫瘍・腎移植の術前評価において、血管解剖の正確な評価は極めて重要である。これまでは侵襲的な血管撮影 が行われてきたが、臨床上では最近 CT angiography がそれに取って代わりつつある。しかしながら美しい画像が すなわち正確な画像であるとは必ずしも言えず、むしろ高精細で美しい画像であるがゆえにその限界が正しく理解 されず、無批判に受け容れられてしまうおそれがある。

そこで本企画では画像診断医の立場から、腎腫瘍および腎移植ドナーに対するマルチスライス CT angiography について症例を中心に提示し、現時点での有用性と限界を明らかにしたい。

そしてこの画像診断手技の限界が臨床上許容できる範囲であると判断されたとき、画像診断の新旧交替があると 考える。

\section{CP4-3}

\section{CT urography and MR urography}

慶應義塾大学放射線診断科

陣崎雅弘

従来、結石を疑う有痛性血尿の患者および腫瘍を疑う無痛性血尿の患者では、排泄性尿路造影(IVU)が第一選択として行われてきた。 しかし、近年へリカルCT が登場してからは、尿路結石を疑う患者ではIVUよりも、造影剤を使わない単純 CTが第一選択として行な われるようになった。これは、単純 CT ではX 線陰性結石も診断できるからであり、その有用性は確立した感がある。

一方、腫瘍性病変を疑った場合には造影は必須である。造影剤を投与してCT で尿路を評価寸る方法は CT urography (CTU) と呼ば れる。肉眼的血尿のようにIVUとCT の両方がおこなわれうる病態に対して行えば、IVUの頻度をさらに減らすことができると考えられ ている。この方法で尿路を評価する場合には、小病変を見つけるために薄いスライス厚を撮る必要があり、機種はマルチスライスCT であることが望ましい。最近の報告によれば、マルチスライス CT の排泄相の横断像を評価すると、IVU以上の情報が得られる。我々の 検討でも、IVU・CTU・MR urography（MRU）の3者ではCTUが最も病変検出能が高いと思われる。

撮像法は、検查前に水 $400 \mathrm{cc}$ を飲ませる。造影剤投与後、5-8 分後に排泄相の CT 撮る。16 スライス CT では $0.5 一 0.6 \mathrm{~mm}$ 程度のス ライス厚を用いて、無理のない息止めの範囲で撮像可能である。基本的には横断像を見ることにより、病変の評価は十分できるが、全体 像の把握のためには 3 次元像が有用である。尿管腫瘍のような水腎症を呈した症例では多断面再構成像を作ることにより、㹨窄部の状態 を十分評価できる。

MRUは、尿路閉塞例に扔いて、尿管拡張の程度・閉塞部位を造影剤を用いることなく描出できることに有用性がある。しかし、上記 のようにマルチスライス CT でも尿路閉塞例の評価も可能になってきている。従って、腎機能が低下しヨード造影剤が使えない症例・被 ばくが重要な問題となる小児例では MRUを使うことになると思われる。

IVU は比較的手軽な検査であるので、この検査がなくなることはないかもしれないが、多くの病態で省略できれば、検査数や造影剤の 使用頻度を減らすことができ、患者にとっての有用性は高いと思われる。 